\title{
Level and conditioning of knowledge about breast cancer displayed by women in perimenopausal age
}

\author{
Renata Bogusz', Ewa Humeniuk², Irena Walecka³, Iwona Bojar ${ }^{4}$ \\ ${ }^{1}$ Independent Medical Sociology Unit, Department of Humanities. Medical University of Lublin, Poland \\ ${ }^{2}$ Institute of Speech Pathology and Rehabilitation, Medical University of Lublin, Poland \\ ${ }^{3}$ Clinic of Dermatology, Central Clinical Hospital, Ministry of Internal Affairs, Warsaw, Poland \\ ${ }^{4}$ Institute of Rural Health in Lublin, Poland
}

Bogusz R, Humeniuk E, Walecka I, Bojar I. Level and conditioning of knowledge about breast cancer displayed by women in perimenopausal age. Ann Agric Environ Med. 2016; 23(2): 324-328. doi: 10.5604/12321966.1203899

\begin{abstract}
Introduction. Women aged 50-69 are the most likely to develop breast cancer. Knowledge about breast tumours as well as regular examination are two of the key factors which reduce the risk of the disease, and increase both the success of treatment and chances of survival.

Objective. The aim of the paper was to assess knowledge about risk factors, symptoms, screening, early diagnosis and breast cancer treatment among women in perimenopausal age.

Materials and method. 400 women aged 45-60, residing in the Lublin region of eastern Poland participated in the research. The primary research tool was a questionnaire with 35 questions checking knowledge about symptoms, screening and early diagnosis, as well as breast cancer treatment. Particulars were also part of the questionnaire.

Results. Over $50 \%$ of women obtained average results with regard to general knowledge, $40 \%$ obtained high results and $6 \%$ low results. Subjective assessment of the women's knowledge was statistically significantly $(p<0.001)$ different from the objective assessment. The research confirmed a significant relationship between knowledge and education $(p<0.01)$, and place of residence $(p<0.001)$. The group examined displayed considerably limited knowledge about risk factors, symptoms, screening, as well as breast cancer early diagnosis and therapy. Over a half of the women in perimenopausal age had average general knowledge, while only $40 \%$ - high.

Conclusions. Over half of the women in perimenopausal age had average general knowledge, while only $40 \%-$ high. Subjective assessment of knowledge differed statistically significantly from the objective assessment. Women with higher education and living in rural areas displayed a higher level of general knowledge about breast cancer. The study did not identified any relationship between level of knowledge about breast cancer and age, financial situation or health of women in perimenopausal age.
\end{abstract}

\section{Key words}

breast cancer, women in perimenopausal age, knowledge about breast cancer

\section{INTRODUCTION}

Breast cancer is the most common malignant tumour in women in the majority of countries worldwide [1]. In Poland, it is the most frequent type of tumour women are diagnosed with (approx. 22\%). It is expected that by 2015 incidence rates will be similar to those observed in Western European countries (approx. 30\%) [2]. Breast cancer is rare among women up to the age of 25 and the risk of falling ill increases with age. Women aged 50-69 are the most likely to develop breast cancer, and in 2008, 57\% of patients diagnosed with breast cancer belonged to this group. Increased death risk concerns primarily women aged over 50; therefore, population screening is directed to this age group $[3,4]$.

The main risk factors for breast cancer are: family predisposition, age above 45 , late first pregnancy (after 35), late menopause, non-cancerous changes, undergoing hormone replacement therapy and hormonal contraception. The following factors may also influence the development

Address for correspondence: Iwona Bojar, Institute of Rural Health in Lublin Jaczewskiego 2, 20-090 Lublin, Poland

E-mail: iwonabojar75@gmail.com

Received: 02 July 2014; accepted: 27 August 2014 of cancerous changes in breasts: obesity, smoking, diet rich in saturated fat and sugar, high cholesterol levels, diabetes, exposition to ionizing radiation [5].

Neoplasm within the mammary gland is a symptom in $80 \%$ cases of breast cancer. Other typical symptoms include: nipple retraction, breast intumescence, skin changes, such as swelling, erythema, satellite nodules, orange peel syndrome, ulceration, skin changes around the nipple, mastitis, serous or bloody serous nipple discharge, swollen axillary lymph nodes [6].

As a part of breast cancer prevention, the Polish AntiCancer Committee and Polish Gynaecological Society defined measures in the case of breast cancer for every woman. These include: self-examination of breasts, physical examination of nipples at a doctor's surgery, screening mammography and gland ultrasonography (sonomammography) [7]. Knowledge about breast tumours and regular preventive examination are one of the key factors which reduce the risk of developing the disease, as well as increasing therapy effectiveness and chances of survival [8].

The aim of the paper was to assess knowledge about risk factors, symptoms, screening, early diagnosis and breast cancer treatment, as observed among women in perimenopausal age. 


\section{MATERIALS AND METHOD}

The survey was conducted in 2012 among 500 randomly chosen women living in the Lublin region of eastern Poland. An additional 400 completed questionnaires underwent further analysis. The research tool, a questionnaire, was constructed on the basis of the latest literature devoted to the subject. It contained 35 questions testing knowledge about symptoms, screening, early diagnosis and treatment of breast cancer. Apart from these, there were also particular questions about the respondent's socio-demographic situation. The researchers determined the level of general knowledge on the basis of answers to 18 questions. The respondents scored 1 point for each correct answer. If the question had several correct answers, 1 point was given for each one, 0 - for none of them, and an adequate split point was given if the respondent mentioned only some of the possible answers. According to the adopted procedure, the respondent could score up to 18 points. The researchers then calculated the percentage of correct answers, and finally set ranges in line with the pattern:

- low results: below $51 \%$ of the highest score;

- average results: $51-75 \%$ of the highest score;

- high results: over $75 \%$.

One of the questions was related to the patient's selfassessment of her own knowledge about risk factors, symptoms, methods used for diagnosis and treatment of breast cancer.

Statistical analysis. The results obtained were then analysed statistically using $\mathrm{Ch}^{2}$ test for independence and $\mathrm{Ch}^{2}$ with Yates' correction for continuity. Differences between two groups were measured using $\mathrm{U}$ test by Mann-Whitney (Z). For more than two groups, Kruskal-Wallis test $(\mathrm{H})$ was applied. The level of significance which would imply statistically significant differences of relations was set at $\mathrm{p}<0.05$. Statistica (StatSoft, Poland) software was used to compile the database and perform statistical analysis.

\section{RESULTS}

The average age in the researched group was 50.8 years, with the youngest woman being 45 , and the oldest -60 . Most of the respondents lived in a city $(87 \%)$ and were married. Others were divorced (13\%), single (7\%) or widowed (4\%). The respondents had secondary or higher education (42\% for each option); $9 \%$ graduated from a vocational school and $7 \%$ finished their education after primary school. Over $2 / 3$ (76\%) of the women were still working. The respondents' financial situation was regarded as average $(53 \%)$, good (43\%) or bad (4\%). When asked about their health state, they most often assessed it at average (50\%) or good (48\%). Only $2 \%$ thought they had bad health.

The first stage of analysis consisted in determining the women's general knowledge about breast cancer, and contrasting it with what they thought it was. (Fig.1).

On average, the respondents scored $71.44 \%$ of the maximum result. Over $50 \%$ of them obtained average scores, $40 \%$ - high and only $6 \%$ - low. Subjective assessment of the women's knowledge was statistically significantly different $(\mathrm{p}<0.001)$ from the objective assessment. Women assessed
Table 1. Characteristics of respondents

\begin{tabular}{|c|c|c|c|}
\hline \multicolumn{2}{|c|}{ Variables } & \multirow{2}{*}{$\frac{N}{148}$} & \multirow{2}{*}{$\begin{array}{l}(\%) \\
37\end{array}$} \\
\hline & under 48 & & \\
\hline \multirow[t]{2}{*}{ Age } & $49-52$ & 116 & 29 \\
\hline & over 52 & 136 & 34 \\
\hline \multirow{2}{*}{ Place of residence } & Town & 348 & 87 \\
\hline & Village & 52 & 13 \\
\hline \multirow{4}{*}{ Marital status } & Married & 304 & 76 \\
\hline & Divorced & 52 & 13 \\
\hline & Singled & 28 & 7 \\
\hline & Widowed & 16 & 4 \\
\hline \multirow{4}{*}{ Education } & Primary & 28 & 7 \\
\hline & Vocational & 36 & 9 \\
\hline & Secondary & 168 & 42 \\
\hline & Higher & 168 & 42 \\
\hline \multirow{3}{*}{ Professional status } & Employed & 304 & 76 \\
\hline & Unemployed & 84 & 21 \\
\hline & Retired & 12 & 3 \\
\hline \multirow{3}{*}{ Financial status } & Good & 172 & 43 \\
\hline & Average & 212 & 53 \\
\hline & Bad & 16 & 4 \\
\hline \multirow{3}{*}{ Health state } & Good & 192 & 48 \\
\hline & Average & 200 & 50 \\
\hline & Bad & 8 & 2 \\
\hline
\end{tabular}

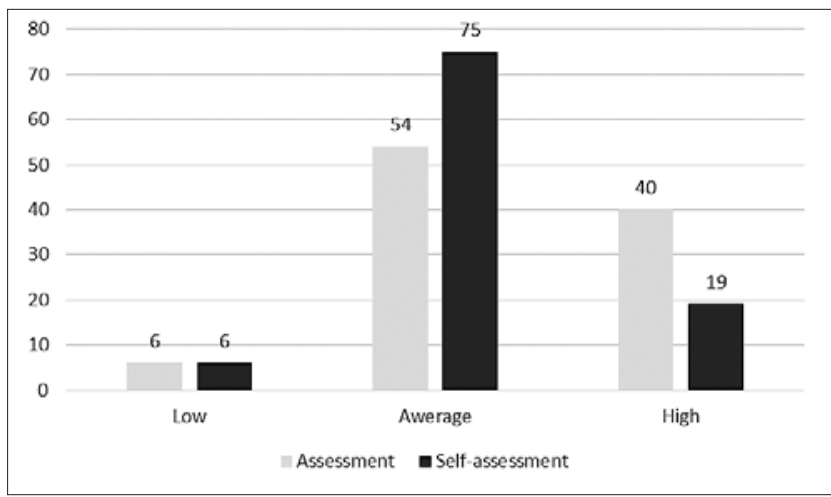

Figure 1. Level and self-assessment of knowledge about risk factors, symptoms, methods for diagnosis and therapy of breast cancer $\chi^{2}=10.893 ; p=0.004$

their knowledge as average $(2 / 3$ of the group), $19 \%$ as high and $6 \%$ as low. Afterwards, which variables influenced the general knowledge about risk factors, symptoms and methods of breast cancer diagnosis and treatment were tested (Fig.2).

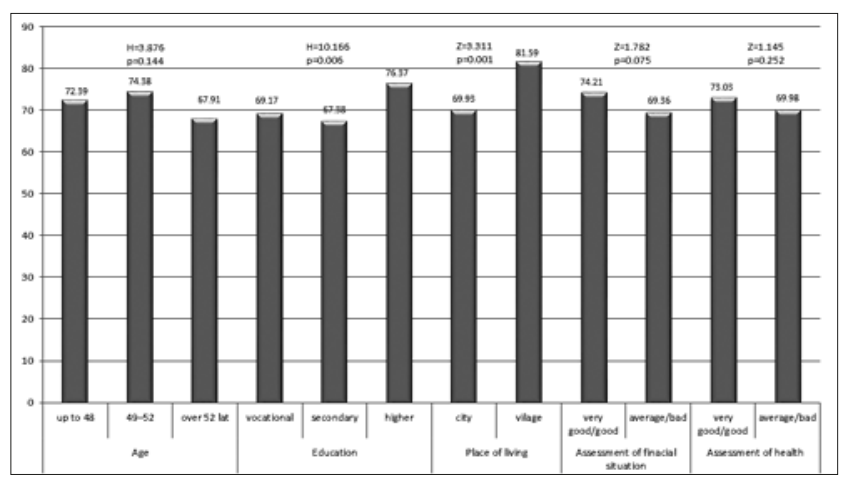

Figure 2. Variables influencing general knowledge about risk factors, symptoms and methods of breast cancer diagnosis and treatment 
Statistical analysis pointed to an existing statistically significant relationship between the women's knowledge and education $(\mathrm{p}<0.01)$, as well as place of residence $(\mathrm{p}<0.001)$. On average, women with higher education who lived in rural areas were closer to the maximal score than city dwellers and women with lower level of education. No significant relationship was observed between knowledge and age, financial situation or state of health.

Next, how much the women knew about risk factors, symptoms and preventive measures taken against breast cancer was tested (Fig. 3,4; Tab.2).

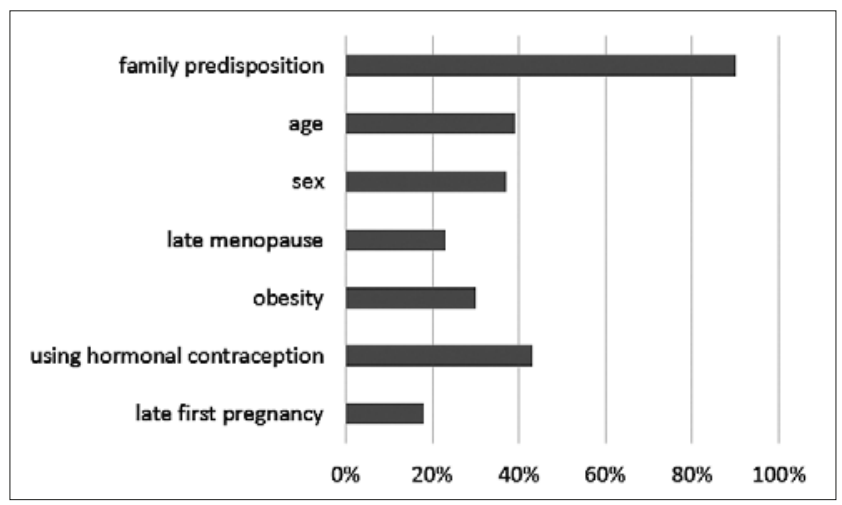

Figure 3. Knowledge of breast cancer risk factors

Genetic predisposition was mentioned as a risk factor by $90 \%$ of respondents. The second most frequent factor was using hormonal contraception (43\%). Over 30\% of the women indicated age and gender, while only $30 \%$ regarded obesity as a risk factor, $23 \%$ stated the same about late menopause, and $18 \%$ mentioned late first pregnancy. Knowledge about risk factors was not related to age $\left(\chi^{2}=1.445 ; \mathrm{p}=0.229\right)$, place of residence $\left(\chi^{2}=7.293 ; \mathrm{p}=0.06\right)$, education $\left(\chi^{2}=1.318\right.$; $\mathrm{p}=0.250)$, financial status $\left(\chi^{2}=2.290 ; \mathrm{p}=0.590\right)$ or state of health $\left(\chi^{2}=0.400 ; \mathrm{p}=0.841\right)$.

Table 2. Knowledge about symptoms that imply breast cancer

\begin{tabular}{lll}
\hline Answers & N & $\%$ \\
\hline Nodule or swelling in the breast & 260 & 65 \\
\hline Bloody or other discharge from the nipple & 208 & 52 \\
\hline Changes in the appearance of breasts & 180 & 45 \\
\hline Pain in the breast & 136 & 34 \\
\hline Swollen lymph nodes & 52 & 13 \\
\hline Nipple retraction & 48 & 12 \\
\hline
\end{tabular}

* Values do not add up to $100 \%$ as the respondents could choose several answers

Most respondents mentioned nodule or swelling in the breast as the first symptoms that imply breast cancer. Over $50 \%$ pointed to bloody or other discharge from the nipple, while $45 \%$ - changes in appearance of the breast(s). The symptoms selected least frequently was swollen lymph nodes (13\%) and nipple retraction (12\%). Knowledge about symptoms that suggest breast cancer did not depend on age $\left(\chi^{2}=1.991 ; \mathrm{p}=0.385\right)$, place of residence $\left(\chi^{2}=2.050 ; \mathrm{p}=0.152\right)$, education $\left(\chi^{2}=0.694 ; \mathrm{p}=0.404\right)$, financial status $\left(\chi^{2}=3.091\right.$; $\mathrm{p}=0.078)$ or state of health $\left(\chi^{2}=1.964 ; \mathrm{p}=0.160\right)$.

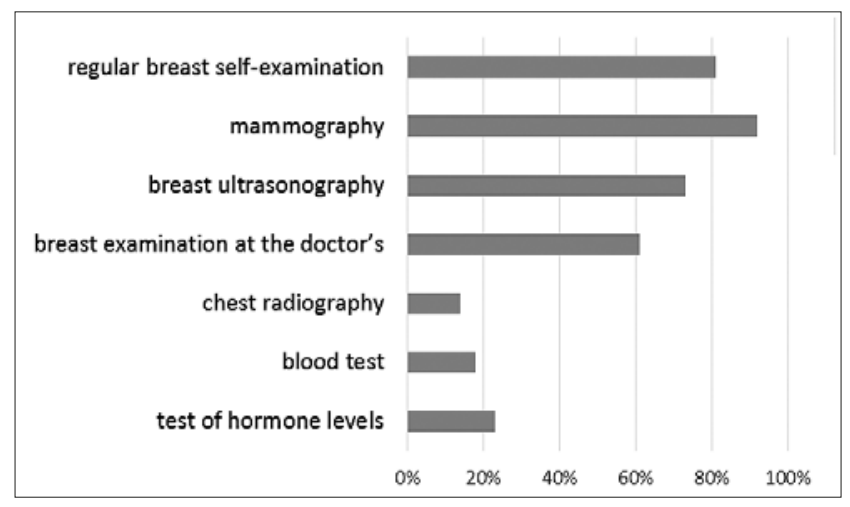

Figure 4. Knowledge about measures taken as part of breast cancer prevention and early diagnosis

Mammography was perceived as a part of breast cancer prevention by $92 \%$ of the respondents; $81 \%$ pointed to the need for regular self-examination of the breasts, $73 \%$ mentioned breast ultrasonography, while $61 \%$ - breast examination at a doctor's surgery. Knowledge about measures taken as part of breast cancer prevention and early diagnosis did not depend on age $\left(\chi^{2}=0.048 ; \mathrm{p}=0.826\right)$, place of residence $\left(\chi^{2}=2.229\right.$; $\mathrm{p}=0.135)$, education $\left(\chi^{2}=0.584 ; \mathrm{p}=0.444\right)$, financial status $\left(\chi^{2}=2.781 ; \mathrm{p}=0.953\right)$ or health state $\left(\chi^{2}=1.786 ; \mathrm{p}=0.181\right)$.

The women were then asked about their knowledge of measures that should be taken in the case of noticing any alarming symptoms (Tab. 3).

Table 3. Women's declarations regarding measures taken in the case of noticing any alarming symptoms

\begin{tabular}{lll}
\hline Answers & N & $\%$ \\
\hline I contact a doctor immediately & 248 & 62 \\
\hline I wait and monitor the changes & 180 & 45 \\
\hline I seek family and friends' advice & 140 & 35 \\
\hline I ignore the problem and pretend everything is fine & 88 & 22 \\
\hline I pray for being cured & 56 & 14 \\
\hline I treat myself with available methods & 36 & 9 \\
\hline I contact a midwife immediately & 12 & 3 \\
\hline
\end{tabular}

* Values do not add up to $100 \%$ as the respondents could choose several answers

In the case of noticing any alarming symptoms, $62 \%$ of the respondents stated immediately contacting a doctor, while $45 \%$ would wait and monitor the changes. As many as 35\% would seek advice among family and friends, $22 \%$ would ignore the problem, $14 \%$ would pray for healing, and $9 \%$ would try treating themselves with available methods. The respondents' declarations about measures taken in the case of noticing any alarming symptoms did not depend on age $\left(\chi^{2}=0.005 ; \mathrm{p}=0.988\right)$, place of residence $\left(\chi^{2}=0.211 ; \mathrm{p}=0.645\right)$, education $\left(\chi^{2}=1.796 ; \mathrm{p}=0.180\right)$, financial status $\left(\chi^{2}=0.762\right.$; $\mathrm{p}=0.382)$ or state of health $\left(\chi^{2}=1.361 ; \mathrm{p}=0.243\right)$.

The final part of the research focused on testing the respondents' knowledge about factors that increase the chances of curing breast cancer (Tab. 4).

All the women agreed that early diagnoses increases the chances of breast cancer being cured. Almost $70 \%$ mentioned appropriate therapy and $41 \%$ pointed to the patient's attitude to therapy. Support from family and friends was less popular $(25 \%)$, and patient-doctor cooperation - undervalued (only $8 \%)$. The women's knowledge about factors that increase 
Table 4. Respondents' knowledge about factors that increase chances of curing breast cancer

\begin{tabular}{lll}
\hline Answers & N & $\%$ \\
\hline Early diagnosis & 400 & 100 \\
\hline Appropriate therapy & 276 & 69 \\
\hline Patient's attitude to therapy & 164 & 41 \\
\hline Family and friends'support & 100 & 25 \\
\hline Age of the patient & 52 & 13 \\
\hline Patient-doctor cooperation & 32 & 8 \\
\hline
\end{tabular}

* Values do not add up to $100 \%$ as the respondents could choose several answers

chances of curing breast cancer was not related to age $\left(\chi^{2}=0.030, \mathrm{p}=0.861\right)$, place of residence $\left(\chi^{2}=2.794 ; \mathrm{p}=0.945\right)$, education $\left(\chi^{2}=0.705 ; \mathrm{p}=0.400\right)$, financial situation $\left(\chi^{2}=1.569\right.$; $\mathrm{p}=0.210)$, or state of health $\left(\chi^{2}=1.369 ; \mathrm{p}=0.241\right)$.

\section{DISCUSSION}

Nowadays, the level of knowledge, which was also the subject of the authors' research, seems to determine people's health-related beliefs and behaviours. More than a half of the respondents in perimenopausal age displayed an average level of general knowledge about breast cancer, while a high level of knowledge was observed among only $40 \%$. Three-quarters assessed their own knowledge as average. In another research on this subject, $3 / 4$ of Polish women admitted that they do not have sufficient information on breast tumour prevention; this was particularly true for young women under the age of 20 (93\%), while those aged over 50 mentioned this less often (59\%) [9].

Researchers in other countries obtained equally low and alarming results. Studies in Malaysia showed that $71 \%$ of women had little knowledge about risk factors for breast cancer [10], and similar observations were made among women in India [11], Western Europe [12, the USA [13], American Indians [14] and Afro-Americans [15]. Only 38\% of women in the early stage of tumour diseases had an average level of knowledge [16]. Surprisingly, an adequate knowledge about breast cancer was displayed by only $57.8 \%$ of nurses in the research by Lemlem et al., and by $25.1 \%$ in a study by Azubuike and Okwuokei $[17,18]$.

The authors' own research has proved that women with an academic education and living in rural areas have a higher level of general knowledge about breast cancer. No relationship was been observed between the level of knowledge and age, financial situation, or state of health. Numerous studies mention the influence of education [19]. Apart from education, other significant factors which increase knowledge about breast cancer include: age, marital status, level of income, type of insurance, and having a family member suffering from a tumour disease $[11,20]$. These relationships have not been observed among the Polish population [21]. The authors' own research among women in perimenopausal age showed that none of the individual elements of knowledge about breast cancer was related to age, place of residence, education, financial status or state of health.

Knowing about risk factors significantly reduces instances of tumours. The respondents most often pointed to family predisposition (90\%), using hormonal contraception (43\%), age (39\%) and gender (37\%). Fewer women knew of such risk factors as obesity (30\%), late menopause (23\%) and late first pregnancy (18\%). In the research by Subramanian et al., genetic predisposition was mentioned by $74.8 \%$, age - by $58.8 \%$, and hormone therapy - by $35.9 \%$. However, about half of the women did not know that late menopause and childlessness are the more dangerous factors than hormone therapy [10]. Also, few women identified obesity as a breast cancer risk factor [19]. In research among medical staff, genetic predisposition was mentioned by $69.6 \%$ of the respondents, smoking - by $54.4 \%$, taking oral contraception - by $36.7 \%$, age - by $31.9 \%$, obesity - by $29.3 \%$, and infertility - by $28.1 \%$. Early first period and late menopause were indicated by $24.4 \%$ and $18.9 \%$, respectively [17]. Polish women most often identified the following risk factors: genes $(62.8 \%)$, smoking (29.7\%), unhealthy diet (22.3\%), hormone medicines (17.3\%), environment pollution and stress (13.2\% each), as well as drinking alcohol or breast injuries (23.1\%) [29]. In the research by Wołoski and Wróblewska, $41 \%$ of the respondents pointed to heredity, $3 \%$ to age and $1 \%$ - excessive consumption of animal fat and alcohol. More than a half of the population (55.2\%) correctly identified all the above-mentioned factors as increasing the risk of breast cancer [23]. Respondents who participated in the research by Najdahor et al. mentioned genetic factors $-78 \%$, age $-52 \%$, contraception $-27 \%$, obesity and childlessness -21\% [4]. In another study, Polish women indicated the following risk factors: smoking (31\%), age (18\%), hormonal contraception (17\%), ionizing radiation (15\%), and excessive weight (2\%) [24]. According to models of health-related behaviours, such little knowledge about risk factors and perception of individual risk may both limit the sensitivity to breast cancer symptoms, establish myths and lead to less regular examination [25].

In the authors' own research, women mentioned the following measures regarded as a part of prevention: mammography (92\%), regular self-examination of breasts (81\%), breast ultrasonography (73\%) and breast examination at a doctor's surgery (61\%). Latest studies show that many women are unaware of prevention methods and early diagnosis of breast cancer $[1,16]$. Although almost $90 \%$ of nurses who completed the questionnaire regarded the methods of early diagnosis as successful in the case of breast cancer, some of them do not perform such an examination [18].

Together with knowledge about risk factors and methods of prevention, it is also essential to know the symptoms that may imply breast tumour. In the authors' research, women most often (65\%) mentioned a nodule or swelling in the breast, bloody or other discharge from the nipple (52\%), and changes in the appearance of the breast(s) (45\%). Swollen lymph nodes (13\%) and nipple retraction (12\%) were the two symptoms underestimated by the respondents. These results are in line with those obtained by other researchers. In the study by Hasanthika et al., most of the respondents were unaware of such early danger symptoms as changes in the appearance of breasts or swollen axillary lymph nodes [1]. Nodule in the breast was the first symptom mentioned by nurses (58.1\%). Others included nipple retraction, breast pain, skin changes of breasts and bloody discharge from the nipple [17]. In population studies, Polish women point to a painless nodule in the breast (73\%) as a symptom of breast cancer. Other symptoms included: bloody discharge from the nipple (40\%), swollen axillary lymph nodes (35\%), asymmetry and swelling (22\%), pain (22\%), reddening, lividity and nipple 
retraction $(21 \%)$ [9]. In another study, the women mentioned nodules (80\%), change of breast shape (40\%), discharge from the nipple (66\%) and nipple retraction (2\%) [24].

Undertaking immediate therapy increases the chances of curing breast cancer. In the case of noticing any alarming symptoms, $62 \%$ of respondents (women in perimenopausal age) would instantly contact a doctor, and $45 \%$ would wait and monitor the changes. Unfortunately, as many as $35 \%$ would only seek advice among family and friends. A number of respondents did not mention any rational behaviour in the case of noticing breast cancer symptoms: $22 \%$ would ignore the problem, 14\% would pray for healing and $9 \%$ would try to treat themselves. Research results obtained by other authors are even more alarming: only $23.6 \%$ would contact a doctor, and $57.8 \%$ would inform their family [1]. Respondents in the early stage of the disease delayed visiting the doctor by $1-72$ months from the moment of noticing the first symptom(s) [16].

\section{CONCLUSIONS}

1. More than a half of the women in perimenopausal age had an average level of general knowledge about breast cancer, while a high level was observed among $40 \%$ of the respondents.

2. Subjective assessment of the women's knowledge was statistically significantly different from the objective assessment.

3. Women with academic education and living in rural areas displayed a higher level of general knowledge about breast cancer.

4. No relationship was observed between the women's knowledge about breast cancer and age, financial situation or state of health.

\section{REFERENCES}

1. Hasanthika M, Ranasinghe, Nilakshika Ranasinghe, Chaturaka Rodrigo, Rohini De A Seneviratne,Senaka Rajapakse. Awareness of breast cancer among adolescent girls in Colombo, Sri Lanka: a school based study BMC Public Health. 2013; 13: 1209.

2. Wojciechowska U, Didkowska J, Zatoński. Nowotwory złośliwe w Polsce w 2009 roku. Warszawa, Ministerstwo Zdrowia, 2011. (in Polish)

3. Lissowska J. Wybrane nowotwory narządów płciowych u kobiet. (in Polish) In: Niemiec T, (eds.). Raport: Zdrowie kobiet w wieku prokreacyjnym 15-49 lat. Warszawa. Wydawca: Program Narodów Zjednoczonych ds. Rozwoju 2007. p. 132-143.

4. Najdyhor E, Krajewska-Kułak E, Krajewska-Ferishah K. Wiedza kobiet i mężczyzn na temat profilaktyki raka piersi. Ginekol Pol. 2013; 84: 116-125. (in Polish)

5. American-Cancer-Society. Breast cancer facts \& figures. Book Breast Cancer Facts \& Figures. City: American Cancer Society, 2010.

6. Senkus E, Jassem J. Rak piersi. In: Wybrane zagadnienie współczesnej onkologii. Krzakowski M. Gdańsk, Via Medica, 2010. (in Polish)

7. Sapczyński M. Rekomendacje Zarządu Głównego PTG w sprawie profilaktyki i wczesnej diagnostyki zmian w gruczole sutkowym (23.03.2005r.). Prz Menopauz. 2005; 2: 8-9. (in Polish)
8. Krzyżak M, Maslach D, Juczewska M, Lasota W, Rabczenko D, Marcinkowski J, Szpak A. Differences in breast cancer incidence and stage distribution between urban and rural female population in Podlaskie Voivodship, Poland in years 2001-2002. Ann Agric Environ Med. 2010; 17(1):159-162.

9. Paździor A, Stachowska M, Zielińska A. Women's knowledge about breast cancer prevention. Now Lek. 2011; 80: 419-422.

10. Subramanian P, Oranye NO, Masri Nur Aishah Taib AM, Ahmad N. Breast Cancer Knowledge and Screening Behaviour among Women with a Positive Family History: A Cross Sectional Study. Asian Pac J Cancer Prev. 2013; 14 (11): 6783-6790.

11. Rahul Sharma, Sanjiv K Bhasin, Sandeep Agrawal, Reeti Tewari. Cancer related knowledge and behavior among women across various socioeconomic strata: A study from Delhi, India. South Asian J Cancer. 2013; 2(2): 66-9.

12. McMenamin M, Barry H, Lennon AM. A survey of breast cancer awareness and knowledge in a western population: lot of light but little illumination. Eur J Cancer. 2005; 41: 393-7.

13. Consedine NS, Magai C, Conway F, Neugut A. Obesity and awareness of obesity as risk factors for breast cancer in six ethnic groups. Obs Res. 2004; 12: 1680-9.

14. Sadler GR, Dhanjal SK, Shah NB, et al. Asian India women: Knowledge, attitudes and behaviors toward breast cancer early detection. Pub Health Nursing. 2001; 18: 357-63.

15. Claire EL Jones, Jill Maben, Ruth H Jack, Elizabeth A Davies, Lindsay JL Forbes, Grace Lucas, and Emma Ream. A systematic review of barriers to early presentation and diagnosis with breast cancer among black women. BMJ Open. 2014; 4(2): e004076.

16. El-Shinawi M, Youssef A, Alsara M, Aly MK, Mostafa M, Yehia A, Hurlbert M, El-Tawab RA, Mohamed MM. Assessing the level of breast cancer awareness among recently diagnosed patients in Ain Shams. Breast. 2013; 22(6): 1210-4.

17. Lemlem SB, Sinishaw W, Hailu M, Abebe M, Aregay A. Assessment of Knowledge of Breast Cancer and Screening Methods among Nurses in University Hospitals in Addis Ababa, Ethiopia, 2011. ISRN Oncol. 2013; 470981 .

18. Azubuike SO, Okwuokei SO. Knowledge, Attitude and Practices of Women Towards Breast Cancer in Benin City, Nigeria Ann Med Health Sci Res. 2013; 3(2): 155-160.

19. Gosein MA, Pinto Pereira SM, Narinesingh D, Ameeral A. Breast Cancer and Mammography: Knowledge, Attitudes, Practices and Patient Satisfaction Post-mammography at the San Fernando General Hospital, Trinidad. J Health Care Poor Underserved. 2014; 25(1): $142-60$.

20. Lemasters T1, Madhavan S, Atkins E, Vyas A, Remick S, Vona-Davis L. "Don't Know" and Accuracy of Breast Cancer Risk Perceptions Among Appalachian Women Attending a Mobile Mammography Program: Implications for Educational Interventions and Patient Empowerment. J Cancer Educ. 2014; 23.

21. Karczmarek-Borowska B, Stryjkowska A, Grądalska-Lampart M, Grybel M. Knowledge of breast cancer among women living in rural areas. Przegląd Medyczny Uniwersytetu Rzeszowskiego i Narodowego Instytutu Leków w Warszawie. Rzeszów 2013; 3: 298-310.

22. Magdalena Florek-Łuszczki. Poziom wiedzy mieszkanek wsi na temat czynników ryzyka zachorowania na nowotwór piersi oraz zasad profilaktyki. Med Og. 2010; 16 (XLV): 406-415. (in Polish)

23. Wołowski T, Wróblewska P. Assessment of knowledge of Gdansk students on the prevention of breast cancer. Probl Hig Epidemiol. 2012; 93(2): 347-349.

24. Cichońska M, Borek M, Krawczyk W, Maciąg D. Women’s knowledge concerning breast tumour and cervical carcinoma prevention. Acta Scientifica Academiae Ostroviensis. 2012; 1: 5-25.

25. Pięta B, Chmaj-Wierzchowska K, Opala T. Life style and risk of development of breast and ovarian cancer. Ann Agric Environ Med. 2012; 19(3): 379-384. 